\title{
A NEW TERRESTRIAL GENUS AND SPECIES WITHIN THE AQUATIC LIVERWORT FAMILY RIELLACEAE (SPHAEROCARPALES) FROM AUSTRALIA ${ }^{1}$
}

\author{
D. Christine CARgilL ${ }^{2} \&$ Josephine Milne
}

\begin{abstract}
A new genus Austroriella Cargill \& Milne and species Austroriella salta Milne \& Cargill within the family Riellaceae is described. Known only from the type location at the margins of a saline lake in Western Australia it is the first record and description of a terrestrial species within this typically aquatic family. Female plants are typical of the family with a single reduced wing bearing a row of archegonia; male plants are not typical and are naviculate in form enclosing several rows of enclosed antheridia not unlike the males of Sphaerocarpos. Unlike Sphaerocarpos this species does bear oil bodies. Differences and affinities are also outlined briefly with closely related genera within the order Sphaerocarpales.
\end{abstract}

Key words: Austroriella, Riella, Riellaceae, Western Australia, saline lakes, aquatic liverworts

D. Christine Cargill, Centre for Australian National Biodiversity Research, GPO Box 1600, Canberra, ACT, Australia 2601, and Australian National Botanic Gardens, GPO Box 1777, Canberra, ACT, Australia. 2601; e-mail: Chris.Cargill@environment. gov.au

Josephine Milne, Royal Botanic Gardens Private Bag 2000 South Yarra 3141, VIC Australia

\section{INTRODUCTION}

Riellaceae is a monogeneric family. There are two species of Riella Mont. (Riellaceae) currently known from Australia: Riella halophila Banwell and R. spiculata J. Taylor. The genus Riella was first collected in Australia on saline mud at the edge of Lochiel Salt Lake, near the north western mallee town of Dimboola, Victoria in 1948. Although this was the first collection, a subsequent collection found on saline mud at a coastal salt marsh, in 1949 at Port Lonsdale, also in Victoria (Fig. 1b), was used to describe Riella halophila (Banwell 1951). Riella spiculata was described in 1954, from material collected from a fresh water marsh near the coastal town of Portland in southwest Victoria (Fig. 1b).

Riella, an ephemeral aquatic liverwort, is commonly found growing in clean, shallow fresh or

\footnotetext{
1 This paper is dedicated to Prof Tamás Pócs, on the occasion of his $80^{\text {th }}$ birthday and for recognition of the enormous contribution he has made to our knowledge of hepatics.

2 Corresponding author
}

brackish water; often in ephemeral habitats. It is well documented that the presence of Riella can be sporadic (Perold 2000) and often it can be decades before plants are relocated at a particular site (Segarra-Moragues et al. 2012b). Some species have been found serendipitously through investigations of other organisms (Wigglesworth 1937) and others are unique collections, not only in number (Segarra-Moragues et al. 2012b) but also from unexpected locations, e.g., a seasonal pool in the Sahara Desert (Puche \& Boisset 2009).

In 2009 during fieldwork in the Swan Valley Plain bioregion (Anonymous 2013) of Western Australia, numerous salt lakes were visited with the aim of finding material of the thalloid liverwort Monocarpus sphaerocarpus D. J. Carr, a rare species known only from a few localities in Australia and a single location in South Africa (Schelpe 1969; Perold 1999).

Whilst searching for $M$. sphaerocarpus at a coastal salt lake north of Perth (Fig. 1a), a population of extremely small bryophytes was 
located on soil in a saline, calcareous sandy rise, near seasonally inundated samphire flats. The vegetation of the sandy rise consists of scattered Tecticornia indica (Willd.) K. A. Sheph. \& P. G. Wilson subsp. bidens (Nees) K. A. Sheph. \& P. G. Wilson and T. pergranulata (J. M. Black) K. A. Sheph. \& Paul G. Wilson, Melaleuca lanceolata Otto, Wilsonia humilis R. Br., Lawrencia sp. and grasses. (Fig. 1c). A collection of this plant was made which on first examination was thought to be either Sphaerocarpos sp. or Monocarpus sp.

A sample of the plant was sent to David Long and Laura Forrest (RBGE) for molecular analysis, which showed the sample cluster within the Riella clade (Forrest et. al. pers. com.). A preliminary analysis combining sequences of four DNA regions found that the Australian specimen was sister to Riella and Sphaerocarpos (Micheli) Boehmer, but was weakly supported. However, in a single region analysis, the sample clustered within the Riella clade (Segarra-Moragues pers. com.).

The Western Australian site was revisited in 2010 and additional material was collected. Although fertile, as was the material collected in the previous year, sporophytes were not mature. A subsequent visit to the site in 2012 failed to find any evidence of the plants. However, upon careful observations, the combination of features typical of the family Riellaceae as well as of the family Sphaerocarpaceae support our conclusion that this is not only a new species but also a genus new to science currently placed within the family Riellaceae.

Descriptions and illustrations of the new genus and species are given here.

\section{TAXONOMY}

\section{Austroriella Cargill \& Milne, gen. nov.}

TYPE SPECIES: Austroriella salta Milne \& Cargill, sp. nov.

Plants amphibious, tiny, 0.3-1.2 mm long, procumbent, in scattered patches. Plants dioicous, females bright green, males becoming chestnut red with maturity. Female plants typical of the family with a single undulating wing bearing oil bodies in individual cells, spherical to pyriform involucre enclosing a beaked calyptra enveloping a spherical capsule. Male plants not typical of the family, naviculate in shape dorsally and falciform in side view. Antheridia in 2 to 5 rows between two wings anteriorly, becoming a single wing posteriorly. Antheridia enclosed within individual involucres appearing dorsally as a uni- or bistratose cover punctuated by an opening above the apex of each antheridium, which are each separated by a wall. Spores released solitary, red-brown, distal face with spine-like protuberances, truncate, rounded or acute at tips.

Austroriella salta Milne \& Cargill, sp. nov.

Figs 2-4

TyPe: AUSTRALIA. Western Australia: Salt lake c. $2 \mathrm{~km} \mathrm{~S}$ from Grigson Lookout. Between Green Head and Jurien Bay, just North of Coastal Road, $29^{\text {th }}$ August 2009, Jolley 175 \& Milne, J (HOLOTYPE MEL; ISOTYPES CANB, PERTH).

Plants dioicous, procumbent, emergent, growing over subsaline soils, posterior partially embedded in the substrate, anterior creeping along surface of substrate, growing in scattered patches, male and female plants growing closely together or singly as individuals, delicate, consisting of an axis and a dorsal wing. Rhizoids all along ventral surface of stem, hyaline and smooth. Male and female plants dimorphic but of similar size in length only.

Male plants naviculate in dorsal view, falciform in side view $0.6-1.2 \mathrm{~mm}$ long, up to $0.4 \mathrm{~mm}$ wide (across dorsal surface from one wing to the other) and $0.16-0.50 \mathrm{~mm}$ high (from ventral surface of stem to margin of wing), stems simple or furcate. Wing double along most of its length, single posteriorly, geminate, on both sides of axis, plane, \pm rectangular in shape, $125-340 \mu \mathrm{m}$ wide (from attachment to stem to margin of wing), unistratose, margins entire, crenate. Wing cells quadrate to hexagonal, isodiametric towards margin of wings, $25-75 \times 20.0-37.5 \mu \mathrm{m}$, becoming elongated towards the stem. Oil cells scattered throughout the wing, each containing a single opaque and rough, oil body. Vegetative scales filamentous or 

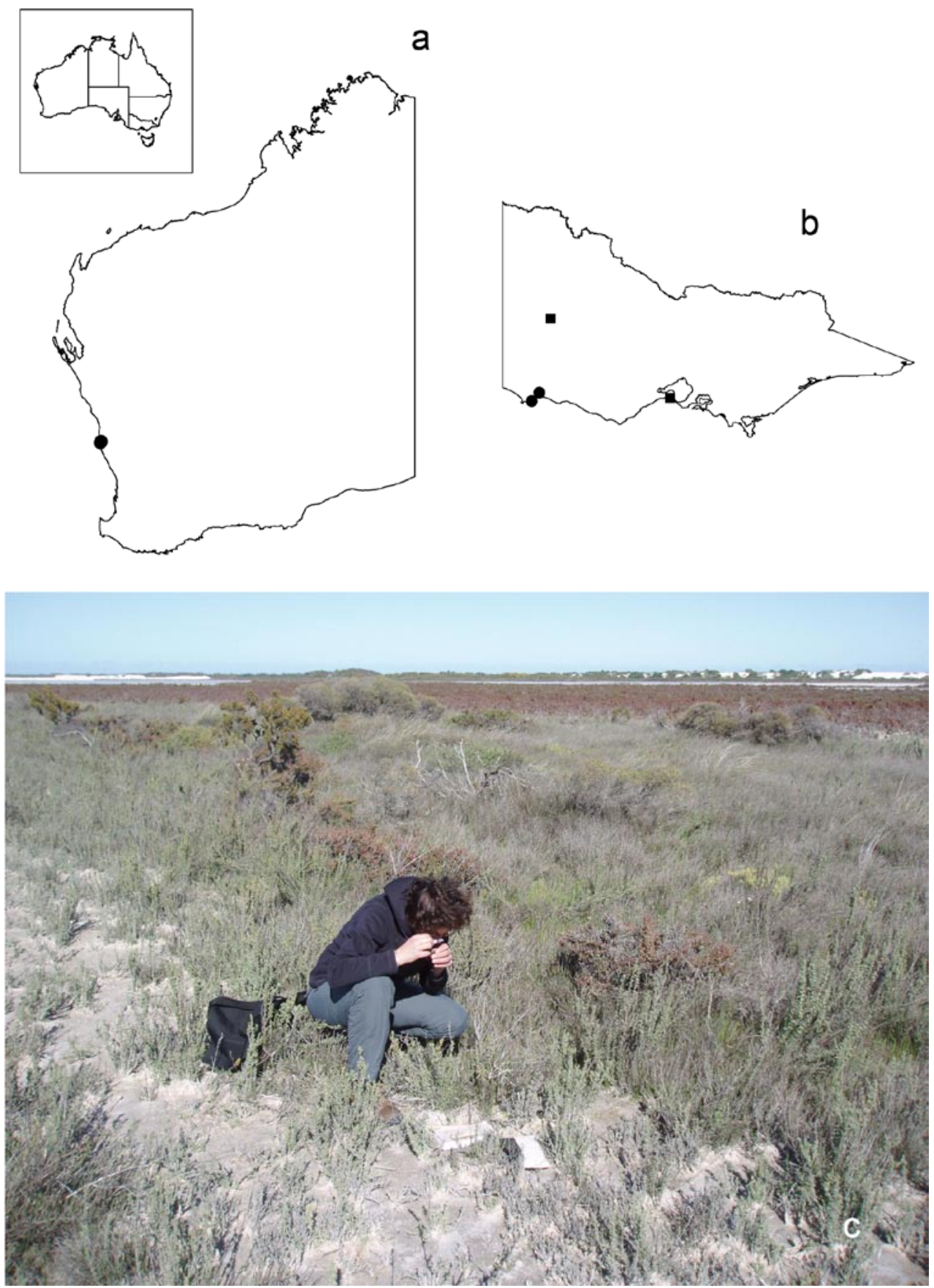

Fig. 1a-c. Distribution of Riella Mont. and Austroriella Cargill \& Milne, gen. nov. in Australia. a - Map of Western Australia showing location of coastal salt lake where Austroriella salta Milne \& Cargill, sp. nov. was collected (inset map of Australia). $\mathrm{b}$ - Map of Victoria showing collection locations of Riella halophila Banwell (squares) and R. spiculata J. Taylor (circles). c - Habitat of Austroriella salta. 


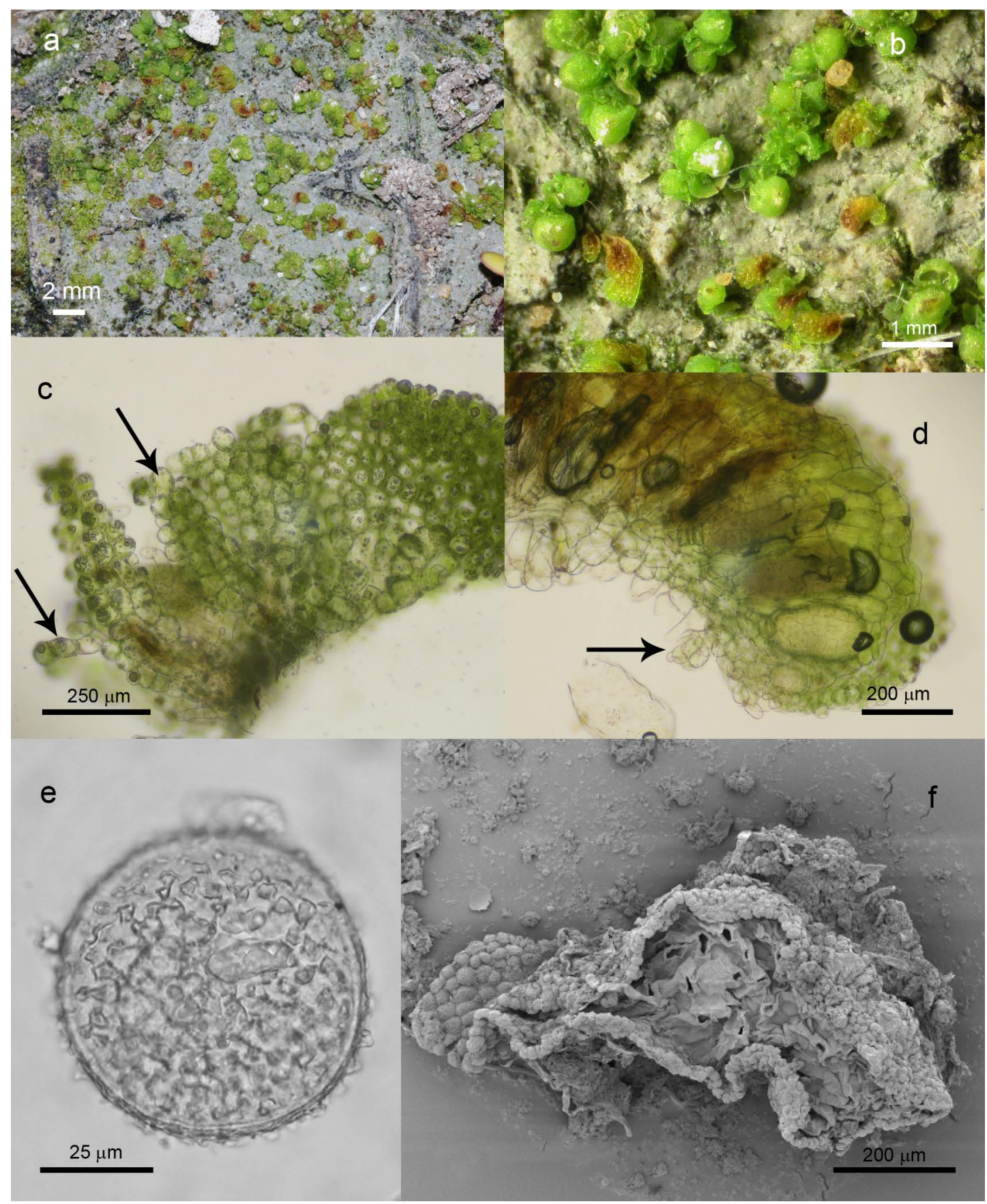

Fig. 2a-f. Austroriella salta Milne \& Cargill, sp. nov. a - population of both male and female plants, $\mathrm{b}$ - close up female plants with sporophytes and males with yellow and chestnut coloured antheridia, $\mathrm{c}-$ wing of female plant with vegetative scales (indicated by arrows), $\mathrm{d}$ - longitudinal section through a male plant showing antheridia and scale (indicated by arrow), $\mathrm{e}-$ light micrograph of distal face of spore, $\mathrm{f}$ - scanning electron micrograph (SEM) of male plant showing double wing and individual involucres of antheridia. 
triangular, along ventral surface of stem or scattered along outside surface of wings, 90-140 $\mu \mathrm{m}$ long and 20-43 $\mu \mathrm{m}$ wide. Propaguliferous scales not seen. Antheridia numerous in two, three or up to five rows between two wings, produced in acropetal sequence, yellow at apex, becoming reddish-orange with maturity. Antheridial body $200 \times 90 \mu \mathrm{m}$, stalked, 3 to 4 cells long, jacket cells untiered.

Female plants ruffled in appearance due to the erect, undulating wing, tiny, $0.32-1.20 \mathrm{~mm}$ long, 0.34-0.81 mm wide (from anterior margin to posterior margin), stems simple or furcate, linear, axis compressed ovoid in cross-section. Wing single, unistratose, undulate, without lobes and rectangular in outline or bilobed and cordate in smaller, younger plants, $180-500 \mu \mathrm{m}$ high from insertion on stem, first cell layer and up to first five layers of cells frequently hyaline, overarching stem apex, wing cells quadrate to hexagonal, isodiametric towards margin of wings, $22.5-80.0 \times 22.5-42.5 \mu \mathrm{m}$ becoming elongated towards stem. Oil cells scattered throughout the wing, each containing a single opaque and rough, oil body. Vegetative scales present and variable in shape from triangular, lanceolate triangular to filamentous, on both sides of wing and surrounding the female involucres, absent along ventral surface of stem, 90-785 $\mu \mathrm{m}$ long and 17.5-133.0 $\mu \mathrm{m}$ wide, with mucilage papillae. Propaguliferous scales not seen. Archegonia at base of wing along stem axis. Involucres 1 or 2 per plant, smooth, no protuberances, but cells bulging giving the surface a papillose appearance, sessile to shortly pedunculate, pyriform to ovoid to \pm spherical, 500-650 $\mu \mathrm{m}$ long and 400-500 $\mu \mathrm{m}$ wide, unistratose, mouth of involucre closed until capsule almost mature, and then open at apex, cells small, quadrate to polygonal in shape, 15.0-57.5 $\times 12.5-42.5 \mu \mathrm{m}$. Sporophyte completely enclosed by calyptra. Calyptra unistratose, with an apical beak (the remains of the archegonial neck), protruding through involucre when mouth open and a pedicel at its base, 90-150 $\mu \mathrm{m}$ long. Capsule spherical, 315-540 $\mu \mathrm{m}$ in diameter, exceedingly short seta, 42-58 $\mu \mathrm{m}$ long and bulbous foot, capsule wall unistratose, cells quadrate to polygonal, $22.5-57.5 \times 20.0-47.5 \mu \mathrm{m}$. Spores red- brown at maturity, hemispherical to tetrahedral, 62.5-75 $\mu \mathrm{m}$ in equatorial diameter including spines. Distal face smooth, covered with short spines, 11-12 across diameter and 30-34 projecting around circumference of spores. Spines $2.50-3.75 \mu \mathrm{m}$ long, $2.5 \mu \mathrm{m}$ wide, with truncate, rounded or acute apices, basal membranes at distal pole interconnected, at the equatorial plane absent. Proximal face convex, triradiate mark indistinct, surface of proximal face rugose. Spines fewer than on distal face, smaller, $2.5 \mu \mathrm{m}$ in diameter, with blunt apices, not interconnected by basal membranes.

ETymology. The generic name is from the Latin Austro-, meaning south or southern referring to its southern hemisphere locality, and -riella in reference to the first genus described for the family Riellaceae.

The species epithet is from the Latin saltus (to jump or leap), in reference to the 'jump' made by this species from the aquatic habitat shared by all other members of the family and alluding in a pleasingly homophonic manner to the saline conditions in which it now grows as a result.

HABITAT. Found growing on bare saline/subsaline soils in swampy marshlands under Tecticornia dominated heathland. Several metres from shore of salt lake, periodically inundated from rainfall only.

DisTRIBUTION. Endemic to Western Australia. Only known from type location.

SPECIMENS EXAMINED: AUSTRALIA. Salt lake c. $2 \mathrm{~km}$ S from Grigson Lookout. Between Green Head and Jurien Bay, between Green Head and Jurien Bay, just North of Coastal Road, Jolley, H.M 176 \& Milne, J., 29 Aug. 2009 (MEL); Salt lake c. 2 km S from Grigson Lookout, Indian Ocean Road, between Green Head and Jurien Bay, Milne, J. 13 Sept. 2010 (MEL).

DISCUSSION. Austroriella salta is characterised primarily by its Sphaerocarpos-like male plants, its smooth, \pm spherical involucre, its procumbent habit and terrestrial habitat preference. Plant cells however, contain oil bodies which place it within the family Riellaceae (Montagne 1852). Both the female and male plants are procumbent, but the female plants are typical of the genus with a stem 


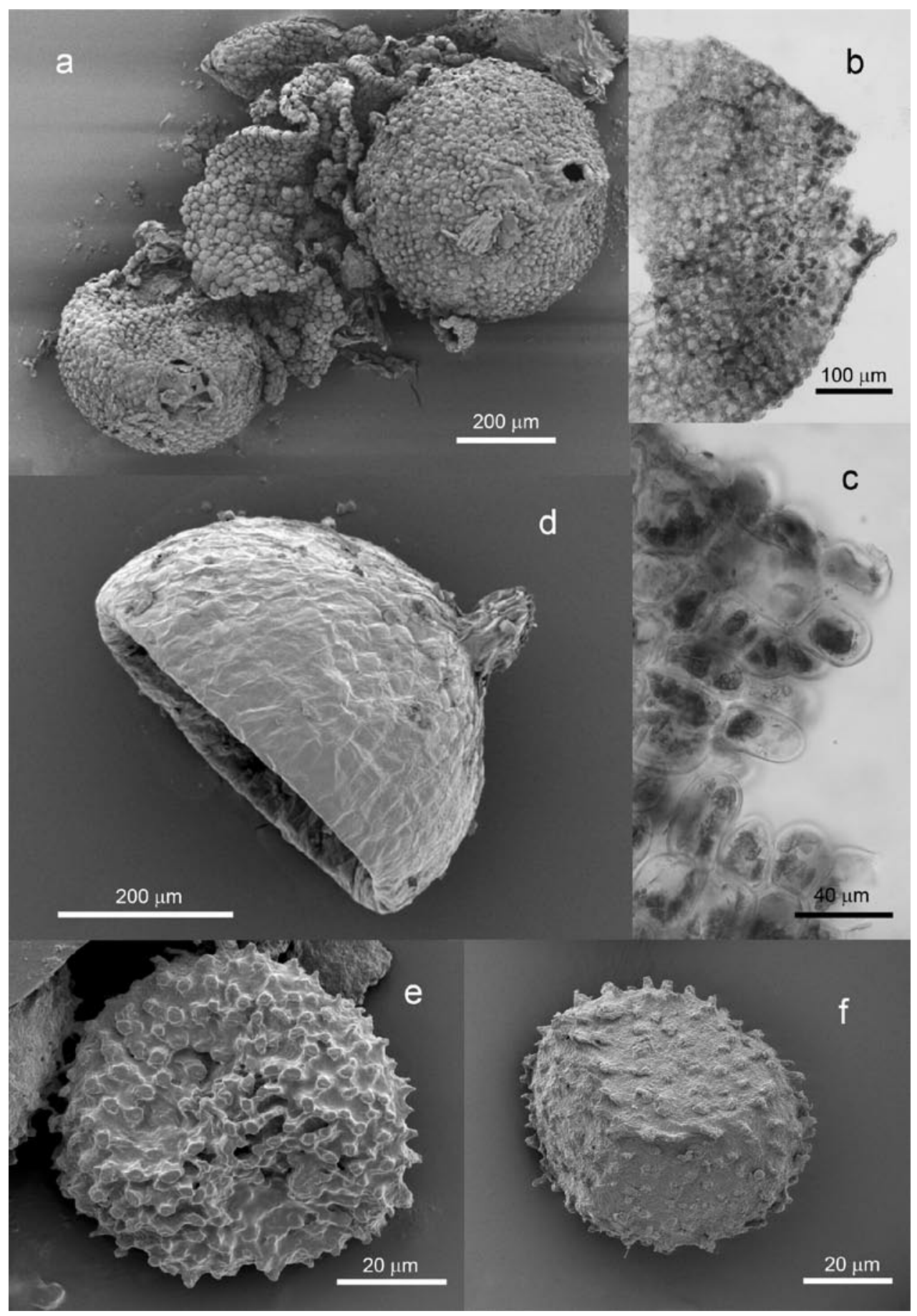

Fig. 3a-f. Female plants of Austroriella salta Milne \& Cargill, sp. nov. a - SEM of whole female plant with sporophyte showing maturing involucre with oriface, $b$ - light micrograph of apex of involucre, $c$ - close up of opening of involucre. $d-S E M$ of calyptra. e - SEM of distal face of spore, $f$ - proximal face of spore. 
Table 1. Comparison of Austroriella salta Milne \& Cargill, sp. nov. with Australian Riella species. Most characters for R. halophila Banwell and $R$. spiculata J. Taylor were taken from protologues. *Actual measurements or observations made by authors when absent from protologues.

\begin{tabular}{|c|c|c|c|}
\hline Characters & Riella halophila & Riella spiculata & Austroriella salta, sp. nov. \\
\hline Plant length & $10-20 \mathrm{~mm}$ & $5-9 \mathrm{~mm}$ & $0.3-1.2 \mathrm{~mm}$ \\
\hline Wing width & $1.5-3.0 \mathrm{~mm}$ & $1.4-3.0 \mathrm{~mm}$ & $0.125-0.810 \mathrm{~mm}$ \\
\hline Vegetative leaf scales & 2-3 mm long & present, $0.3-0.5 \mathrm{~mm}$ long & $0.090-0.785 \mathrm{~mm}$ long \\
\hline Sexual state & dioicous & monoicous & dioicous \\
\hline Antheridia & $\begin{array}{l}\text { antheridia not in single row; } \\
\text { embedded in free margin }\end{array}$ & $\begin{array}{l}\text { immersed in wing, and } \\
\text { grouped in marginal sinuses in } \\
\text { single row }\end{array}$ & $\begin{array}{l}\text { two to five rows between two } \\
\text { wings }\end{array}$ \\
\hline \multicolumn{4}{|l|}{ Involucre } \\
\hline shape & pyriform - subglobose & ovoid acuminate & pyriform to ovoid \\
\hline size & $2.0-3.0 \mathrm{~mm}$ long & $2.0-2.5 \mathrm{~mm}$ long & $0.50-0.65 \mathrm{~mm}$ long \\
\hline ribbed or smooth & smooth & smooth & smooth \\
\hline Stalk & pedunculate & sessile & sessile to shortly pedunculate \\
\hline Seta length & ${ }^{*} 300-470 \mu \mathrm{m}$ & ${ }^{*} 250 \mu \mathrm{m}$ & $42-58 \mu \mathrm{m}$ \\
\hline Foot shape & $\begin{array}{l}{ }^{*} \pm \text { bulbous, slightly broader } \\
\text { than seta }\end{array}$ & ${ }^{*}$ slight flaring of base of seta & bulbous \\
\hline \multicolumn{4}{|l|}{ Capsule } \\
\hline shape & spherical & spherical & spherical \\
\hline size & ${ }^{*} \sim 550 \mu \mathrm{m}$ & ${ }^{*} 660-850 \mu \mathrm{m}$ & $315-540 \mu \mathrm{m}$ \\
\hline \multicolumn{4}{|l|}{ Spores } \\
\hline diameter & $\begin{array}{l}62-72 \mu \mathrm{m} \text { excluding spines, } \\
{ }^{*} 65-76 \mu \mathrm{m} \text { including spines }\end{array}$ & $\begin{array}{l}80 \mu \mathrm{m} \text { excluding spines, } \\
99 \mu \mathrm{m} \text { including spines }\end{array}$ & $\begin{array}{l}60.0-72.5 \mu \mathrm{m} \text { in equatorial } \\
\text { diameter, excluding spines, } \\
62.5-75.0 \mu \mathrm{m} \text { including spines }\end{array}$ \\
\hline wing & *absent & "absent & absent \\
\hline shape & subelliptical & subtriangular - circular & hemispherical to tetrahedral \\
\hline $\begin{array}{l}\text { ornamentation of distal } \\
\text { face }\end{array}$ & *short spine-like protuberances & $\begin{array}{l}\text { central reticulation and } \\
\text { trunucated spines }\end{array}$ & short, spine-like protuberances \\
\hline length of spines & $3-4(-5) \mu \mathrm{m}$ & ${ }^{*} 7.5-12.5 \mu \mathrm{m}$ & $2.50-3.75 \mu \mathrm{m}$ \\
\hline apices of spines & obtuse or truncate & truncate & $\begin{array}{l}\text { apex rounded, truncate or } \\
\text { acute }\end{array}$ \\
\hline basal membrane & $\begin{array}{l}{ }^{*} \text { present at distal pole, absent } \\
\text { at equatorial plane }\end{array}$ & *distinct across distal face & $\begin{array}{l} \pm \text { distinct, present at distal } \\
\text { pole, absent at equatorial plane }\end{array}$ \\
\hline $\begin{array}{l}\text { \# of spines across } \\
\text { diameter }\end{array}$ & ${ }^{*} 7-9$ & $* 9-11$ & $11-12$ \\
\hline $\begin{array}{l}\text { ornamentation of } \\
\text { proximal face }\end{array}$ & *scattered irregular papillae & *finely papillate & small scattered papillae \\
\hline triradiated mark & *absent & faint & indistinct \\
\hline
\end{tabular}

bearing a single lateral wing. The male in contrast is a curved stem bearing two wings, which enclose several rows of antheridia, (Figs 2d, 4a) more typically seen in male plants of Sphaerocarpos. In Riella, they occur in single rows along the margin of the wing (Perold 2000; SegarraMoragues et al. 2012a, b). Little is known of the complete life cycle of this species as it has only been collected twice over two consecutive years from its type locality and is not yet in cultivation. Very little is known of the vegetative state of the male plants before they become fertile, if indeed there is a vegetative state.

Austroriella salta differs from both $R$. halophila and $R$. spiculata by the shape of its involucre which is \pm spherical to pyriform to ovoid and sessile to very shortly pedunculate, (Figs $3 \mathrm{a}, 4 \mathrm{e}, \mathrm{f}$ ) while that of $R$. halophila is pyriform-subglobose 


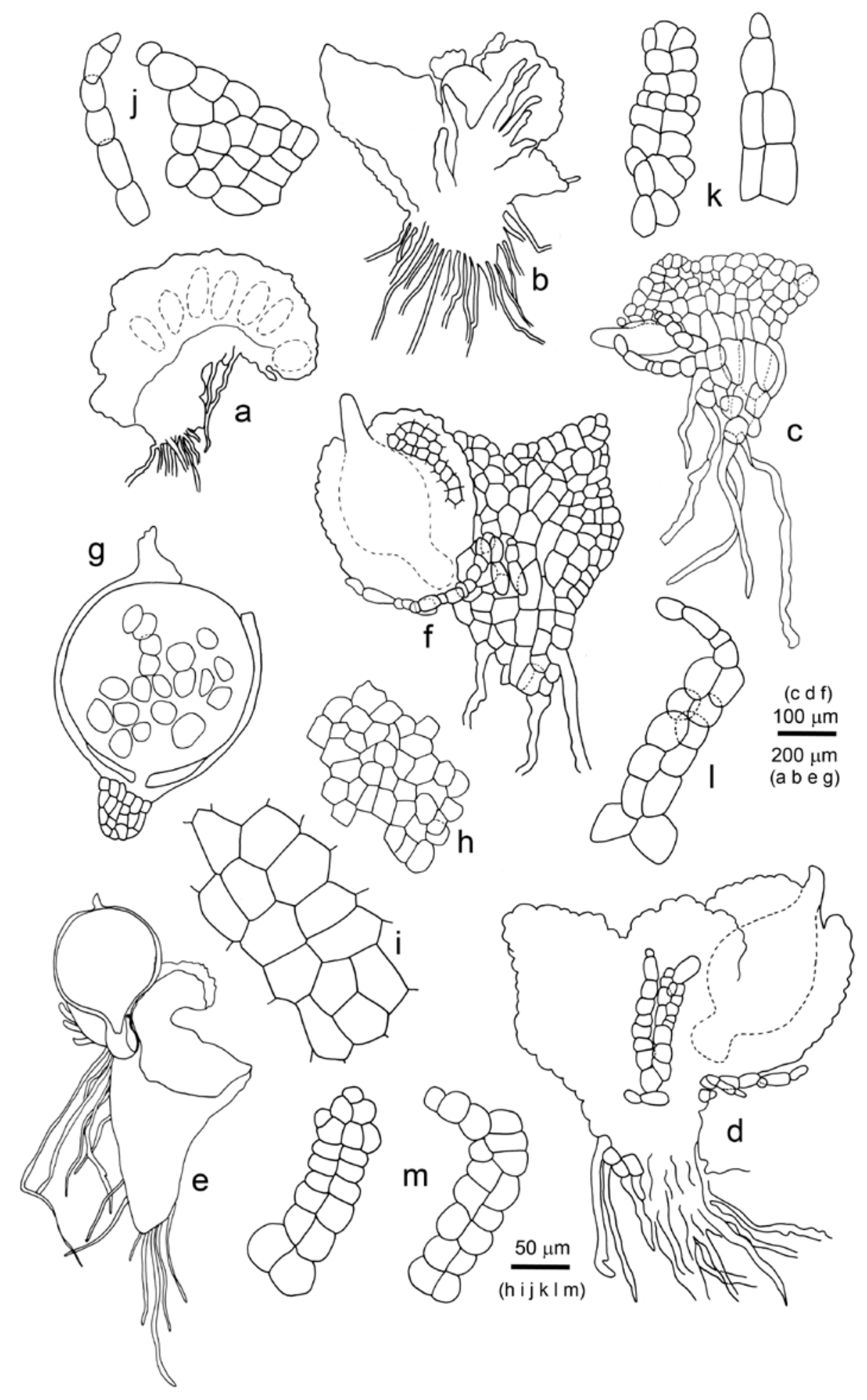


and distinctly pedunculate (Banwell 1949) and $R$. spiculata is ovoid-acuminate or tear-dropshaped and also in the monoicous sexual condition of the latter (Taylor 1954).

Other prominent differences between the three species can be seen in the spore patterning which is considered an important character for distinguishing species. Riella spiculata has the most distinct spores, with the distal face displaying a macro-ornamentation of long slender protuberances which flare at the tips, and a fine reticulated patterning in between the interconnected basal membranes. (Taylor 1954). The spores of $R$. halophila and A. salta are similar with a distal macro-ornamentation of low spinelike protuberances however, A. salta has many more across the diameter of the distal face (Figs 2e, 3e). (Table 1).

Members of the Riellaceae are elusive plants within the hepatic flora or Australia. The family is considered to include obligate aquatic species found in swamps and marshlands, often in brackish, subsaline or saline conditions around the edges of salt lakes or saltpans. As noted by Segarra-Moragues, these habitats occupied by this genus are not readily sort out by bryologists (Segarra-Moragues et al. 2012a) because of the paucity of bryophytes. Austroriella salta is unusual in the sense that it appears to be a terrestrial species, its life cycle ephemeral and probably triggered by seasonal inundation from rain. Fertile plants to date were collected in Spring following a wet Winter. Its prostrate habit also indicates that this species does not grow to maturity when under water as is typical of the genus (Segarra-Moragues et al. 2012a \& b). The habitat is situated in scrubby heathland within the Swan Coastal Plain bioregion (Anonymous 2013) on saline soil, however $A$. salta is at a significant distance from the edge of the more permanent water of the saline lake (Fig. 1c), hence the assumption that it is not an obligate aquatic species within the genus but a terrestrial species.
Recent molecular multi-locus analyses have supported a clade containing all members of the order Sphaerocarpales (Sphaerocarpos, Geothallus, Riella and Austroriella) plus Monocarpus in a sister relationship to this group (Forrest et al. 2012). Characters which unite members of the Sphaerocarpales are the absence of air chambers, air pores and elaters, presence of only smooth rhizoids, antheridia in perigonial involucres or pockets, a very short seta and cleistocarpous capsules (Crandall-Stotler et al. 2009). Monocarpus, which is currently classified within the order Marchantiales (Crandall-Stotler et al. 2009), does bear air pores. It does share with Sphaerocarpos and Geothallus the absence of oil bodies, absence of ventral scales and the absence of specialized asexual structures all of which are found in Riella and Austroriella.

ACKNOWLEDGEMENTS. We thank José Gabriel SegarraMoragues for his assistance with confirming the identity of the plants and for feedback on the description, Laura Forrest and David Long (RBGE) for sharing their molecular analysis results and Directors of AD and MEL for providing access to and loan of specimens, Helen Jolley for her SEM images, Alison Vaughan (MEL) for production of the locality maps, Nunzio Knerr for help with figures.

\section{REFERENCES}

ANONYMOUS 2013. Australia's Bioregions (IBRA7) [April 2013]. http://www.environment.gov.au/parks/nrs/science/ bioregion-framework/ibra.

BANWELl A. D. 1951 A new species of Riella from Australia. Trans. Brit. Bryol. Soc. 1: 475-478.

Crandall-Stotler B., Stotler R. E. \& Long D. 2009. Morphology and classification of the Marchantiophyta. In: B. GOFFINET \& A. J. SHAW (eds), Bryophyte biology, $2^{\text {nd }}$ ed., pp. 1-54. Cambridge University Press, Cambridge.

Forrest L. L, Schill D., Hollingsworth M. L., LONG D. G., Cargill D. C., Jolley H. M., Milne J. 2012. On Monocarpus International symposium of molecular systematics of bryophytes. (Poster). In: W. R. BUCK, B.

Fig. 4a-m. Line drawings of Austroriella salta Milne \& Cargill, sp. nov. a - male plant,. b - vegetative plant with lateral scales, $\mathrm{c}$ - whole female plant, $\mathrm{d}-\mathrm{f}-$ whole female plants with lateral scales and developing sporophytes, $\mathrm{g}-$ sporophyte covered by calyptra, $\mathrm{h}$ - cells of involucre, $\mathrm{i}$ - cells of capsule, $\mathrm{j}-\mathrm{m}$ - vegetative scales. 
Goffinet, A. LitT \& D. Poli (eds), 3rd International Symposium on Molecular Systematics of Bryophytes (June 20-22, 2012), p. 79. New York Botanical Garden, New York.

Montagne C. 1852. Note sur le genere Riella et description d'une espèce nouvelle $R$. reuteri. Ann. Sci. Nat. (Paris) 18: 11-13.

Perold S. M. 1999. Studies in the Sphaerocarpales (Hepaticae) from southern Africa. 1. The genus Monocarpus and its only member, M. sphaerocarpus. Bothalia 29: 225-230.

Perold S. M. 2000. Studies in the Sphaerocarpales (Hepaticae) from southern Africa. 3. The genus Riella and its local species. Bothalia 30: 125-142.

PUCHE F. \& BOISSET F. 2009. On the occurrence of Riella affinis M.Howe et Underwood (Marchantiopsida, Sphaerocarpales) in the Sahara Desert (Africa). Cryptog. Bryol. 30: $217-226$.
SCHELPE E. A. C. L. E. 1969. Three new records of Southern Hemisphere Bryophyta for South Africa. J. S. African Bot. 35: 109-112.

Segarra-Moragues J. G., Puche F. \& SAbovljević M. 2012a. Rediscovery of Riella alatospora (Riellaceae, Sphaerocarpales), an aquatic, South African endemic liverwort previously know from largely transformed type locality. S. African J. Bot. 79: 32-38.

Segarra-Moragues J. G., Puche F. \& Sabovljević M. 2012b. Riella heliospora (Riellaceae) a new monoicous species of Riella subgenus Trabutiella from California. Syst. Bot. 37: 307-219.

TAYlor J. 1954. A new Australian hepatic. Kew Bull. 9: $45-47$.

Wigglesworth G. 1937. South African species of Riella, including an account on the development stages of three of the species. Journal of the Linnean Society of London, Botany 51: 309-332.

Received 19 April 2013 